medRxiv preprint doi: https://doi.org/10.1101/2021.02.05.21250953; this version posted February 5, 2021. The copyright holder for this preprint (which was not certified by peer review) is the author/funder, who has granted medRxiv a license to display the preprint in perpetuity.

All rights reserved. No reuse allowed without permission.

\title{
Convalescent Plasma and Improved Survival in Patients with Hematologic Malignancies
} and COVID-19

Michael A. Thompson, MD, PhD, FASCO ${ }^{1 *}$; Jeffrey P. Henderson, MD, PhD, FIDSA ${ }^{2^{*}}$; Pankil K. Shah, MD, MSPH ${ }^{3}$; Samuel M. Rubinstein, MD; Michael J. Joyner, MD ${ }^{5}$; Toni K. Choueiri, MD Daniel B. Flora, MD, PharmD7; Elizabeth A. Griffiths, MD $^{8}$; Anthony P. Gulati, MD ${ }^{9}$; Clara Hwang, MD ${ }^{10}$; Vadim S. Koshkin, MD ${ }^{11}$; Esperanza B. Papadopoulos, MD ${ }^{12}$; Elizabeth V. Robilotti, MD, MPH ${ }^{12}$; Christopher T. Su, MD MPH ${ }^{13}$; Elizabeth M. Wulff-Burchfield, MD ${ }^{14}$; Zhuoer Xie, MD, MS ${ }^{5}$; Peter Paul Yu, MD, FASCO ${ }^{15}$; Sanjay Mishra, MS, PhD ${ }^{16}$; Jonathon W. Senefeld, $\mathrm{PhD}^{5}$; Dimpy P. Shah, MD, PhD ${ }^{3^{*}}$; Jeremy L. Warner, MD, MS, FAMIA, FASCO ${ }^{16^{*}}$; on behalf of the COVID-19 and Cancer Consortium

${ }^{*}$ contributed equally

\#To whom correspondence should be addressed: Jeremy L. Warner, MD, MS, FAMIA, FASCO.

2220 Pierce Ave PRB 777, Nashville, TN 37232. +1 (615) 322-5464. jeremy.warner@vumc.org

${ }^{1}$ Aurora Cancer Care, Advocate Aurora Health, Milwaukee, W

${ }^{2}$ Washington University School of Medicine, St. Louis, MO, USA

${ }^{3}$ Mays Cancer Center at UT Health San Antonio MD Anderson, San Antonio, TX, USA

${ }^{4}$ University of North Carolina Lineberger Comprehensive Cancer Center, Chapel Hill, NC, USA

${ }^{5}$ Mayo Clinic Cancer Center, Rochester, MN, USA

${ }^{6}$ Dana-Farber Cancer Institute, Boston, MA, USA

${ }^{7}$ St. Elizabeth Healthcare, Edgewood, KY, USA

${ }^{8}$ Roswell Park Comprehensive Cancer Center, Buffalo, NY, USA

${ }^{9}$ Stamford Hospital, Stamford, CT, USA

${ }^{10}$ Henry Ford Cancer Institute, Detroit, MI, USA

${ }^{11}$ UCSF Helen Diller Family Comprehensive Cancer Center at the University of California San

Francisco, San Francisco, CA, USA

${ }^{12}$ Memorial Sloan Kettering Cancer Center, New York, NY, USA

${ }^{13}$ University of Michigan Rogel Cancer Center, Ann Arbor, MI, USA

${ }^{14}$ University of Kansas Medical Center, Kansas City, KS, USA

${ }^{15}$ Hartford Health Care, Farmington, CT, USA

${ }^{16}$ Vanderbilt University Medical Center/Vanderbilt-Ingram Cancer Center, Nashville, TN, USA 
medRxiv preprint doi: https://doi.org/10.1101/2021.02.05.21250953; this version posted February 5, 2021. The copyright holder for this preprint (which was not certified by peer review) is the author/funder, who has granted medRxiv a license to display the preprint in perpetuity.

All rights reserved. No reuse allowed without permission.

\section{Summary}

Convalescent plasma may benefit immunocompromised individuals with COVID-19, including those with hematologic malignancy. We evaluated the association of convalescent plasma treatment with 30-day mortality in hospitalized adults with hematologic malignancy and COVID19 from a multi-institutional cohort. 143 treated patients were compared to 823 untreated controls. After adjustment for potential confounding factors, convalescent plasma treatment was associated with improved 30-day mortality (hazard ratio, $0.60 ; 95 \% \mathrm{Cl}, 0.37-0.97$ ). This association remained significant after propensity-score matching (hazard ratio, $0.52 ; 95 \% \mathrm{Cl}$, 0.29-0.92). These findings suggest a potential survival benefit in the administration of convalescent plasma to patients with hematologic malignancy and COVID-19. 
medRxiv preprint doi: https://doi.org/10.1101/2021.02.05.21250953; this version posted February 5, 2021. The copyright holder for this preprint (which was not certified by peer review) is the author/funder, who has granted medRxiv a license to display the preprint in perpetuity.

All rights reserved. No reuse allowed without permission.

\section{BACKGROUND}

Since initial reports in late 2019, SARS Coronavirus-2 (SARS-CoV-2) has infected over 100 million people worldwide and caused over 2 million deaths by early $2021 .{ }^{1}$ To date, data guiding COVID-19 therapies have largely arisen from large scale studies of healthy adults. Patients with hematologic malignancy represent a distinctive subset of COVID-19 patients due to immune deficits associated with both the diseases themselves and their treatments. Hematologic malignancy has been consistently associated with increased COVID-19 mortality and other complications..$^{2-4}$

Antibody-based immunity is an important correlate of SARS-CoV-2 recovery and vaccineassociated prevention. Hematologic malignancies are associated with defects in humoral and cellular immunity that may contribute to adverse COVID-19 outcomes. Impaired antibody function is a well described complication of plasma cell neoplasms, chronic lymphocytic leukemia, and other lymphoid malignancies. Treatment of hematologic malignancies often exacerbate these immune defects; for example, rituximab targets the pan-B cell marker, CD20, and is highly effective therapy for B-cell malignancies. However, B-cell depletion can cause lymphopenia and hypogammaglobulinemia, and is associated with more severe COVID-19. ${ }^{5}$ Lymphopenia is known to be associated with more severe COVID-19. ${ }^{6}$

Antibody therapy using COVID-19 convalescent plasma was associated with a therapeutic benefit in a general patient population ${ }^{7}$ and older patients ${ }^{8}$ when high titer units were administered early in the course of disease. A negative prospective randomized trial included only 4 patients with hematologic malignancy in the convalescent plasma group. ${ }^{9}$ In immunodeficient patients, case reports have noted exceptional improvements in clinical status following convalescent plasma therapy, even following relatively late infusion. ${ }^{10}$ Given the absence of definitive prospective trial data in patients with hematologic malignancy, we 
medRxiv preprint doi: https://doi.org/10.1101/2021.02.05.21250953; this version posted February 5, 2021. The copyright holder for this preprint (which was not certified by peer review) is the author/funder, who has granted medRxiv a license to display the preprint in perpetuity.

All rights reserved. No reuse allowed without permission.

conducted a retrospective cohort study to evaluate the hypothesis that convalescent plasma can correct defects in humoral deficiency and improve outcomes.

\section{METHODS}

\section{Setting}

The COVID-19 and Cancer Consortium (CCC19) is an international consortium aimed at understanding the clinical impact of COVID-19 on patients with cancer through an IRBexempted comprehensive registry (NCT04354701). The methodology for CCC19 has been

described and published previously. ${ }^{11}$ We analyzed data from hospitalized U.S. adults with a current or past diagnosis of hematologic malignancy diagnosed with confirmed or suspected SARS-CoV-2 infection in 2020 and reported from March $17^{\text {th }}, 2020$ to January $21^{\text {st }}, 2021$ (full list of contributors is in the Supplementary Appendix). Treatment exposure was defined as receiving convalescent plasma at any time during the COVID-19 illness. The exclusion criteria were: incomplete follow-up resulting in unknown death status, unknown or missing convalescent plasma exposure, age <18 years, mild COVID-19 not requiring hospitalization, and non-U.S. residence. The following data elements were obtained: age; sex; race and ethnic group; smoking status; comorbidities; the first recorded absolute lymphocyte count; type of hematologic malignancy; cancer status at COVID-19 diagnosis; Eastern Cooperative Oncology Group (ECOG) performance status prior to COVID-19; receipt and timing of anti-cancer treatment; baseline COVID-19 severity; level of care required; other anti-COVID-19 therapies (i.e., corticosteroids, remdesivir, tocilizumab, hydroxychloroquine); and U.S. census region of patient's residence. The full data dictionary is provided in the Supplementary Appendix.

\section{Statistical Analysis}

We calculated bivariate frequencies to examine the associations among the baseline characteristics and receipt of convalescent plasma. The primary endpoint was death within 30 
medRxiv preprint doi: https://doi.org/10.1101/2021.02.05.21250953; this version posted February 5, 2021. The copyright holder for this preprint (which was not certified by peer review) is the author/funder, who has granted medRxiv a license to display the preprint in perpetuity.

All rights reserved. No reuse allowed without permission.

days of COVID-19 diagnosis. Living patients had their data censored at 30 days from diagnosis. Crude and adjusted hazards ratios and $95 \% \mathrm{Cl}$ to estimate the association between convalescent plasma use and 30-day all-cause mortality were calculated using Cox proportional-hazards regression models. The primary analysis used propensity-score matching to help account for the nonrandomized treatment administration of convalescent plasma. ${ }^{12}$ Individual propensities for receipt of convalescent plasma treatment were estimated using a multivariable probit regression model with baseline covariate adjustment using covariates that were determined a priori based on published literature and clinical importance: age, sex, race/ethnicity, hematologic malignancy type, cancer status, cancer treatment timing, ECOG performance status, obesity, presence of type 2 diabetes mellitus, hypertension, renal comorbidities, pulmonary comorbidities, receipt of cytotoxic chemotherapy within 3 months of COVID-19 diagnosis, and trimester of diagnosis [January to April 2020; May to August 2020; September to December 2020]). For matching, the nearest-neighbor method with a 1:1 ratio (treated units:control units) and 0.2 standard deviation of the distance measure was applied to estimate the average treatment effect. ${ }^{13}$ Marginal hazard ratio along with $95 \% \mathrm{Cl}$ based on cluster-robust standard errors are reported. Kaplan-Meier survival curves were generated to compare survival probabilities using log-rank and stratified log-rank tests between convalescent plasma recipients and non-recipients for unmatched and matched samples, respectively. We conducted several sensitivity analyses to explore the robustness of the findings for the primary hypothesis against the model specifications, such as varying the caliper size by $+/-0.1$ and changing the matching order from the default maximum distance first to random order with different seeds. Exploratory subgroup analyses were conducted to determine whether patients with more severe illness (intensive care unit admission and/or mechanical ventilation) had differential outcome by convalescent plasma exposure. 
medRxiv preprint doi: https://doi.org/10.1101/2021.02.05.21250953; this version posted February 5, 2021. The copyright holder for this preprint (which was not certified by peer review) is the author/funder, who has granted medRxiv a license to display the preprint in perpetuity.

All rights reserved. No reuse allowed without permission.

We interpreted findings based on the $95 \% \mathrm{Cl}$ for the estimated measures of association.

Reported P values are two-sided. Statistical analyses were performed using $\mathrm{R}$ software, version 4.0.3 (with packages Matchlt and Survival).

\section{RESULTS}

As of January $21^{\text {st }}, 2021$, the CCC19 registry contained 8209 case reports with complete baseline information. $1761(21.5 \%)$ patients had a primary or secondary hematologic malignancy, with lymphoid malignancies being the most common. After applying eligibility criteria (Supplemental Figure S1), there were n=966 patients, of whom $143(14.8 \%)$ received convalescent plasma treatment (Supplemental Figure S2). Patient characteristics are noted in Table 1. Median age was 67 (interquartile range 58 to 77 ). In the unmatched sample, convalescent plasma recipients were slightly younger and more likely to be male. A lower proportion of convalescent plasma recipients had pulmonary comorbidities and ECOG performance status of 2 or more compared to the unexposed group. Convalescent plasma recipients were also more likely to be treated with corticosteroids, tocilizumab, and/or remdesivir, and less likely with hydroxychloroquine. Overall, $512(53 \%)$ patients had received systemic anticancer treatment within 3 months of COVID-19 diagnosis, with targeted therapies (monoclonal antibodies, small molecule inhibitors, and/or immunomodulators) being the most commonly received treatments. $115(22 \%)$ of those treated received an anti-CD20 antibodycontaining regimen. Overall, $489(58 \%)$ of 845 patients with absolute lymphocyte count available had lymphopenia $\left(<1.5 \times 10^{9}\right.$ cells/liter $)$ at presentation; this proportion increased to $79 \%$ in patients who had received anti-CD20 antibodies. Propensity-score matching was successful, with good balance achieved between the exposed and non-exposed groups (Supplement Figures S3-S5). Convalescent plasma recipients were more likely to require aggressive care (intensive care unit admission and/or mechanical ventilation). 
medRxiv preprint doi: https://doi.org/10.1101/2021.02.05.21250953; this version posted February 5, 2021. The copyright holder for this preprint (which was not certified by peer review) is the author/funder, who has granted medRxiv a license to display the preprint in perpetuity.

All rights reserved. No reuse allowed without permission.

With a median follow-up period of 30 days (interquartile range 21 to 90 days), there were 223 (23.1\%) deaths within 30 days of COVID-19 diagnosis (Table 2). The crude hazard rate for mortality was significantly lower in convalescent plasma recipients (19 out of $143 ; 13.3 \%$ ), compared to non-recipients (204 out of $823 ; 24.8 \%$ ). This difference was statistically significant after adjustment in the overall comparison (hazard ratio, $0.60 ; 95 \% \mathrm{Cl}, 0.37$ to $0.97 ; \mathrm{P}=0.033$ ) and the propensity-score matched comparison (hazard ratio, $0.52 ; 95 \% \mathrm{Cl}, 0.29$ to 0.92 ; $\mathrm{P}=0.025$ ) (Table 2). Non-recipients had significantly lower overall survival than those who received convalescent plasma in the unmatched and matched samples (Figure 1). Multiple additional sensitivity analyses, including analyses that used different caliper sizes for matching and analyses with randomized matching orders, showed similar results. Among the 338 patients admitted to the intensive care unit, the crude hazard rate for mortality was significantly lower in convalescent plasma recipients compared to non-recipients in the overall comparison (adjusted hazard ratio, $0.30 ; 95 \% \mathrm{Cl}, 0.16$ to 0.56 ) and the propensity-score matched comparison (hazard ratio, $0.40 ; 95 \% \mathrm{Cl}, 0.20$ to 0.80 ). Among the 227 patients requiring mechanical ventilation, the crude hazard rate for mortality was significantly lower in convalescent plasma recipients compared to non-recipients in the overall comparison (hazard ratio, $0.23 ; 95 \% \mathrm{Cl}, 0.10$ to 0.50 ) and the propensity-score matched comparison (hazard ratio, $0.32 ; 95 \% \mathrm{Cl}, 0.14$ to 0.72 ) (Table

\section{2; Supplemental Figure S6).}

\section{DISCUSSION}

There is historical evidence demonstrating the efficacy of passive antibody therapy for infectious diseases when given early in the course of disease prior to the development of endogenous antibody responses, including in severe acute respiratory infections. ${ }^{14-16}$ On this basis, interventional trials of convalescent plasma in COVID-19 are ongoing; to our knowledge, only one of these, FALP-COVID (NCT04384588) is specifically recruiting patients with cancer. There is accumulating evidence supporting the efficacy of convalescent plasma in patients with 
medRxiv preprint doi: https://doi.org/10.1101/2021.02.05.21250953; this version posted February 5, 2021. The copyright holder for this preprint (which was not certified by peer review) is the author/funder, who has granted medRxiv a license to display the preprint in perpetuity.

All rights reserved. No reuse allowed without permission.

primary or secondary immunodeficiency, including those subjected to profound immunosuppression in the setting of hematopoietic stem cell transplantation. ${ }^{17,18}$ Patients with hematologic malignancies may have immune deficiencies from patient factors (including age), disease factors, and treatment factors. For example, in a single center cohort of patients with chronic lymphocytic leukemia (a common B-cell hematologic malignancy) who had documented symptomatic COVID-19, 7 of 21 (33\%) did not develop detectable anti-SARS-CoV-2 antibodies, notably lower than the $100 \%$ seroconversion rate observed in a non-cancer population. ${ }^{19,20}$ Several small studies have demonstrated improvement in clinical course after administration of convalescent to patients with cancer, primarily hematologic malignancy. ${ }^{21-23}$ Clinical improvement in COVID-19 symptoms within 48 hours of convalescent plasma transfusion was also reported in 16 of 17 patients with B-cell lymphopenia and prolonged COVID-19, 15 of whom had received anti-CD20 therapy in the 3-6 months prior to symptoms onset. ${ }^{23}$

Lymphopenia was common in our study population, especially in patients with recent anti-CD20 treatment, as would be expected. We are unable to ascertain rates of hypogammaglobulinemia, as this was not a routinely collected variable. The exact mechanism by which convalescent plasma may have mediated improved outcomes in the treated patients is likely multifactorial, and could include reduction in viral load via enhanced clearance ${ }^{23}$ reduction in secondary bacterial and fungal infections, neutralization of inflammatory cytokines that may otherwise promote a hyperinflammatory immune phenotype,${ }^{24}$ and temporizing until the native immune system generates additional humoral and cell-mediated responses in the recovery phase after myelosuppressive or lymphodepleting anticancer therapy.

Our study is the largest such series reported to date, to our knowledge. Due to the multiinstitutional nature of the data with over 70 contributing institutions (Supplemental Appendix), these findings are unlikely to be the result of specific practice patterns at certain institutions. Variables collected through this effort, such as cancer status, prior cancer treatments, and 
medRxiv preprint doi: https://doi.org/10.1101/2021.02.05.21250953; this version posted February 5, 2021. The copyright holder for this preprint (which was not certified by peer review) is the author/funder, who has granted medRxiv a license to display the preprint in perpetuity.

All rights reserved. No reuse allowed without permission.

ECOG performance status, are not readily available through automated electronic health record extractions or claims databases.

Limitations of this study include its retrospective nature, as well as unmeasured variables, such as the exact timing of convalescent plasma administration with respect to the date of COVID-19 diagnosis, the antibody titers/levels in the plasma that was administered, and whether repeat dosing was employed. Despite propensity matching, it is possible that residual confounding remains, and results should be interpreted with caution. For example, even after propensity matching, the convalescent plasma recipients received more corticosteroids and remdesivir. Although these agents have not been shown to have a clear survival benefit in cancer populations,${ }^{25}$ it is possible that at least part of the observed protective effect of convalescent plasma could be due to concomitant medications, including fewer administrations of hydroxychloroquine. Convalescent plasma non-recipients may have received less aggressive care overall due to factors other than COVID-19, e.g., advanced states of cancer; this possibility is partially addressed through adjustment for cancer status. Differential access to convalescent plasma due to health system or socioeconomic factors cannot be excluded. It is possible that the findings in the first 30 days would not persist into later periods, which would require a more extended follow-up. Therefore, like any observational study, these findings should not be inferred for causality but rather be seen as contributing to the accumulating evidence regarding survival benefit with convalescent plasma in patients with COVID-19 illness. Prospective randomized trials evaluating convalescent plasma in patients with hematologic malignancy with attention to administration timing and consideration of repeated dosing are recommended.

In conclusion, convalescent plasma appears to confer a survival benefit in patients with hematologic malignancy and COVID-19. If this finding should hold up in prospective clinical trials, convalescent plasma would be, to our knowledge, the first COVID-19 intervention with a survival benefit in this high-risk population. 
medRxiv preprint doi: https://doi.org/10.1101/2021.02.05.21250953; this version posted February 5, 2021. The copyright holder for this preprint (which was not certified by peer review) is the author/funder, who has granted medRxiv a license to display the preprint in perpetuity.

All rights reserved. No reuse allowed without permission.

\section{ACKNOWLEDGMENTS}

We thank all members of the CCC19 steering committee: Toni K. Choueiri, Dimitrios Farmakiotis, Petros Grivas, Gilberto de Lima Lopes Jr., Corrie A. Painter, Solange Peters, Brian I. Rini, Dimpy P. Shah, Michael A. Thompson, and Jeremy L. Warner, for their invaluable guidance of the CCC19 consortium. This project has been funded in whole or in part with Federal funds from the Department of Health and Human Services; Office of the Assistant Secretary for Preparedness and Response; Biomedical Advanced Research and Development Authority under Contract No. 75A50120C00096; National Cancer Institute (NCI) grants P30 CA008748, P30 CA046592, P30 CA054174, P30 CA068485, T32 CA236621, and U01 CA231840; National Center for Advancing Translational Sciences (NCATS) grant UL1 TR002377; Schwab Charitable Fund (Eric E Schmidt, Wendy Schmidt donors); United Health Group; National Basketball Association (NBA); Millennium Pharmaceuticals; Octapharma USA, Inc; the American Cancer Society and Hope Foundation for Cancer Research grant MRSG-16152-01-CCE; the Longer Life Foundation: A RGA/Washington University Partnership; and the Mayo Clinic. REDCap is developed and supported by Vanderbilt Institute for Clinical and Translational Research grant support (UL1 TR000445 from NCATS/NIH).

Disclaimer: The views and opinions expressed in this publication are those of the authors and do not reflect the official policy or position of the US Department of Health and Human services and its agencies including the Biomedical Research and Development Authority and the Food and Drug Administration, as well as any agency of the U.S. government. Assumptions made within and interpretations from the analysis are not reflective of the position of any U.S. government entity. 
medRxiv preprint doi: https://doi.org/10.1101/2021.02.05.21250953; this version posted February 5, 2021. The copyright holder for this preprint (which was not certified by peer review) is the author/funder, who has granted medRxiv a license to display the preprint in perpetuity.

All rights reserved. No reuse allowed without permission.

\section{REFERENCES}

1. COVID-19 Map [Internet]. Johns Hopkins Coronavirus Resour. Cent. [cited 2021 Jan 30];Available from: https://coronavirus.jhu.edu/map.html

2. Kuderer NM, Choueiri TK, Shah DP, et al. Clinical impact of COVID-19 on patients with cancer (CCC19): a cohort study. The Lancet 2020;395(10241):1907-18.

3. Robilotti EV, Babady NE, Mead PA, et al. Determinants of COVID-19 disease severity in patients with cancer. Nat Med 2020;26(8):1218-23.

4. Wood WA, Neuberg DS, Thompson JC, et al. Outcomes of patients with hematologic malignancies and COVID-19: a report from the ASH Research Collaborative Data Hub. Blood Adv 2020;4(23):5966-75.

5. Kow CS, Hasan SS. Use of rituximab and the risk of adverse clinical outcomes in COVID19 patients with systemic rheumatic disease. Rheumatol Int 2020;1-2.

6. Tan L, Wang Q, Zhang D, et al. Lymphopenia predicts disease severity of COVID-19: a descriptive and predictive study. Signal Transduct Target Ther 2020;5(1):1-3.

7. Joyner MJ, Carter RE, Senefeld JW, et al. Convalescent Plasma Antibody Levels and the Risk of Death from Covid-19. N Engl J Med 2021;0(0):null.

8. Libster R, Pérez Marc G, Wappner D, et al. Early High-Titer Plasma Therapy to Prevent Severe Covid-19 in Older Adults. N Engl J Med 2021;

9. Simonovich VA, Burgos Pratx LD, Scibona P, et al. A Randomized Trial of Convalescent Plasma in Covid-19 Severe Pneumonia. N Engl J Med 2020;

10. Senefeld JW, Klassen SA, Ford SK, et al. Therapeutic use of convalescent plasma in COVID-19 patients with immunodeficiency. medRxiv 2020;2020.11.08.20224790.

11. Abidi M, Aboulafia DM, Accordino MK, et al. A Systematic Framework to Rapidly Obtain Data on Patients with Cancer and COVID-19: CCC19 Governance, Protocol, and Quality Assurance. Cancer Cell 2020;38(6):761-6.

12. D'Agostino RB. Propensity score methods for bias reduction in the comparison of a treatment to a non-randomized control group. Stat Med 1998;17(19):2265-81.

13. Austin PC. Optimal caliper widths for propensity-score matching when estimating differences in means and differences in proportions in observational studies. Pharm Stat 2011;10(2):150-61.

14. Casadevall A, Scharff MD. Return to the past: the case for antibody-based therapies in infectious diseases. Clin Infect Dis Off Publ Infect Dis Soc Am 1995;21(1):150-61.

15. Mair-Jenkins J, Saavedra-Campos M, Baillie JK, et al. The Effectiveness of Convalescent Plasma and Hyperimmune Immunoglobulin for the Treatment of Severe Acute Respiratory Infections of Viral Etiology: A Systematic Review and Exploratory Meta-analysis. J Infect Dis 2015;211(1):80-90. 
medRxiv preprint doi: https://doi.org/10.1101/2021.02.05.21250953; this version posted February 5, 2021. The copyright holder for this preprint

(which was not certified by peer review) is the author/funder, who has granted medRxiv a license to display the preprint in perpetuity.

All rights reserved. No reuse allowed without permission.

16. Casadevall A, Pirofski L-A. The convalescent sera option for containing COVID-19. J Clin Invest 2020;130(4):1545-8.

17. Shah GL, DeWolf S, Lee YJ, et al. Favorable outcomes of COVID-19 in recipients of hematopoietic cell transplantation. J Clin Invest 2020;130(12):6656-67.

18. Algwaiz G, Aljurf M, Koh M, et al. Real-World Issues and Potential Solutions in Hematopoietic Cell Transplantation during the COVID-19 Pandemic: Perspectives from the Worldwide Network for Blood and Marrow Transplantation and Center for International Blood and Marrow Transplant Research Health Services and International Studies Committee. Biol Blood Marrow Transplant 2020;26(12):2181-9.

19. Roeker LE, Knorr DA, Pessin MS, et al. Anti-SARS-CoV-2 antibody response in patients with chronic lymphocytic leukemia. Leukemia 2020;34(11):3047-9.

20. Long Q-X, Liu B-Z, Deng H-J, et al. Antibody responses to SARS-CoV-2 in patients with COVID-19. Nat Med 2020;26(6):845-8.

21. Ferrari S, Caprioli C, Weber A, Rambaldi A, Lussana F. Convalescent hyperimmune plasma for chemo-immunotherapy induced immunodeficiency in COVID-19 patients with hematological malignancies. Leuk Lymphoma 2021;0(0):1-9.

22. Tremblay $D$, Seah $C$, Schneider $T$, et al. Convalescent Plasma for the Treatment of Severe COVID-19 Infection in Cancer Patients. Cancer Med 2020;9(22):8571-8.

23. Hueso $\mathrm{T}$, Pouderoux $\mathrm{C}$, Péré $\mathrm{H}$, et al. Convalescent plasma therapy for B-cell-depleted patients with protracted COVID-19. Blood 2020;136(20):2290-5.

24. Rojas M, Rodríguez Y, Monsalve DM, et al. Convalescent plasma in Covid-19: Possible mechanisms of action. Autoimmun Rev 2020;19(7):102554.

25. Rivera DR, Peters S, Panagiotou OA, et al. Utilization of COVID-19 Treatments and Clinical Outcomes among Patients with Cancer: A COVID-19 and Cancer Consortium (CCC19) Cohort Study. Cancer Discov 2020;10(10):1514-27. 


\section{TABLES}

Table 1: Characteristics of Patients Receiving or Not Receiving Convalescent Plasma before and after Propensity-Score Matching. CP: COVID-19 convalescent plasma

\begin{tabular}{|c|c|c|c|c|}
\hline \multirow{2}{*}{$\begin{array}{l}\text { Variable } \\
\text { - no. (\%) }\end{array}$} & \multicolumn{2}{|c|}{ Unmatched Patients } & \multicolumn{2}{|c|}{$\begin{array}{c}\text { Propensity-Score Matched } \\
\text { Patients }\end{array}$} \\
\hline & $\begin{array}{c}C P \\
(N=143)\end{array}$ & $\begin{array}{c}\text { No CP } \\
(N=823)\end{array}$ & $\begin{array}{c}C P \\
(N=143)\end{array}$ & $\begin{array}{c}\text { No } C P \\
(N=143)\end{array}$ \\
\hline \multicolumn{5}{|l|}{ Age } \\
\hline $18-39 \mathrm{yr}$ & $12(8.4)$ & $54(6.6)$ & $12(8.4)$ & $15(10.5)$ \\
\hline $40-59 \mathrm{yr}$ & $37(25.9)$ & $174(21.1)$ & $37(25.9)$ & $38(26.6)$ \\
\hline $60-69 \mathrm{yr}$ & $45(31.5)$ & $233(28.3)$ & $45(31.5)$ & $45(31.5)$ \\
\hline $70-79 \mathrm{yr}$ & $31(21.7)$ & $209(25.4)$ & $31(21.7)$ & $28(19.6)$ \\
\hline$\geq 80 \mathrm{yr}$ & $18(12.6)$ & $153(18.6)$ & $18(12.6)$ & $17(11.9)$ \\
\hline \multicolumn{5}{|l|}{ Sex } \\
\hline Male & $82(57.3)$ & $457(55.5)$ & $82(57.3)$ & $85(59.4)$ \\
\hline Female & $61(42.7)$ & $366(44.5)$ & $61(42.7)$ & $58(40.6)$ \\
\hline \multicolumn{5}{|l|}{ Race and ethnic group } \\
\hline Non-Hispanic white & $81(56.6)$ & $413(50.2)$ & $81(56.6)$ & $73(51.0)$ \\
\hline Non-Hispanic Black & $19(13.3)$ & $174(21.1)$ & $19(13.3)$ & $29(20.3)$ \\
\hline Hispanic & $26(18.2)$ & $152(18.5)$ & $26(18.2)$ & $24(16.8)$ \\
\hline Other & $16(11.2)$ & $70(8.5)$ & $16(11.2)$ & $13(9.1)$ \\
\hline Missing/Unknown & $1(0.7)$ & $14(1.7)$ & $1(0.7)$ & $4(2.8)$ \\
\hline \multicolumn{5}{|l|}{ Smoking } \\
\hline Never & $82(57.3)$ & $446(54.2)$ & $82(57.3)$ & $71(49.7)$ \\
\hline Former/Current & $58(40.6)$ & $349(42.4)$ & $58(40.6)$ & $68(47.6)$ \\
\hline
\end{tabular}




\begin{tabular}{|c|c|c|c|c|}
\hline Missing/Unknown & $3(2.1)$ & $28(3.4)$ & $3(2.1)$ & $4(2.8)$ \\
\hline \multicolumn{5}{|l|}{ Comorbidity } \\
\hline Hypertension & $80(55.9)$ & $485(58.9)$ & $80(55.9)$ & $75(52.4)$ \\
\hline Obesity & $53(37.1)$ & $282(34.3)$ & $53(37.1)$ & $53(37.1)$ \\
\hline Diabetes Mellitus & $38(26.6)$ & $259(31.5)$ & $38(26.6)$ & $41(28.7)$ \\
\hline Pulmonary & $19(13.3)$ & $191(23.2)$ & $19(13.3)$ & $19(13.3)$ \\
\hline Renal & $32(22.4)$ & $182(22.1)$ & $32(22.4)$ & $31(21.7)$ \\
\hline \multicolumn{5}{|l|}{ ECOG Performance Status } \\
\hline 0 & $37(25.9)$ & $196(23.8)$ & $37(25.9)$ & $40(28.0)$ \\
\hline 1 & $53(37.1)$ & $267(32.4)$ & $53(37.1)$ & $57(39.9)$ \\
\hline $2+$ & $17(11.9)$ & $172(20.9)$ & $17(11.9)$ & $15(10.5)$ \\
\hline Unknown & $36(25.2)$ & $188(22.8)$ & $36(25.2)$ & $31(21.7)$ \\
\hline \multicolumn{5}{|l|}{$\begin{array}{l}\text { Method of COVID-19 } \\
\text { diagnosis }^{1}\end{array}$} \\
\hline Laboratory-confirmed & $138(96.5)$ & $798(97.0)$ & 138 (96.5) & $140(97.9)$ \\
\hline Suspected & $5(3.5)$ & $23(2.8)$ & $5(3.5)$ & $<5(<3.5)^{8}$ \\
\hline \multicolumn{5}{|l|}{ Baseline COVID-19 severity } \\
\hline Mild & $25(16.9)$ & $147(17.9)$ & $25(16.9)$ & $29(20.3)$ \\
\hline Moderate & $79(55.6)$ & $503(61.1)$ & $79(55.6)$ & $87(60.8)$ \\
\hline Severe & 34 (23.9) & $166(20.2)$ & $34(23.9)$ & $24(16.8)$ \\
\hline Missing/Unknown & $5(3.5)$ & $7(0.9)$ & $5(3.5)$ & $3(2.1)$ \\
\hline \multicolumn{5}{|l|}{ Level of care required } \\
\hline Hospitalization $^{2}$ & $142(99.3)$ & $823(100)$ & $142(99.3)$ & $143(100)$ \\
\hline Intensive Care Unit admission & $76(53.1)$ & $262(31.8)$ & $76(53.1)$ & $41(28.7)$ \\
\hline Mechanical Ventilation & $45(31.5)$ & $182(22.1)$ & $45(31.5)$ & $29(20.3)$ \\
\hline
\end{tabular}




\begin{tabular}{|c|c|c|c|c|}
\hline $\begin{array}{l}\text { Other medications received } \\
\text { during CoviD-19 illness }\end{array}$ & & & & \\
\hline Corticosteroid & $79(55.2)$ & $229(27.8)$ & $79(55.2)$ & $44(30.8)$ \\
\hline Remdesivir & $72(50.3)$ & $153(18.6)$ & $72(50.3)$ & $35(24.5)$ \\
\hline Hydroxychloroquine & $34(23.8)$ & $272(33.0)$ & $34(23.8)$ & $42(29.4)$ \\
\hline Tocilizumab & $19(13.3)$ & $54(6.6)$ & $19(13.3)$ & $8(5.6)$ \\
\hline Absolute lymphocyte count & & & & \\
\hline Normal & $33(23.1)$ & $240(29.2)$ & $33(23.1)$ & $46(32.2)$ \\
\hline Low & $79(55.2)$ & $410(49.8)$ & $79(55.2)$ & $72(50.3)$ \\
\hline High & $13(9.1)$ & $70(8.5)$ & $13(9.1)$ & $8(5.6)$ \\
\hline Unknown/Not-drawn & $18(12.6)$ & $103(12.5)$ & $18(12.6)$ & $17(11.9)$ \\
\hline Type of hematologic \\
malignancy
\end{tabular}




\begin{tabular}{|c|c|c|c|c|}
\hline $\begin{array}{l}\text { Timing of anti-cancer } \\
\text { treatment relative to } \\
\text { COVID-19 diagnosis }\end{array}$ & & & & \\
\hline$<3$ months & $86(60.1)$ & $449(54.6)$ & $86(60.1)$ & $84(58.7)$ \\
\hline$>3$ months & $39(27.3)$ & $237(28.8)$ & $39(27.3)$ & $40(28.0)$ \\
\hline $\begin{array}{l}\text { Never or started after } \\
\text { COVID-19 diagnosis }\end{array}$ & $16(11.2)$ & 120 (14.6) & $16(11.2)$ & $17(11.9)$ \\
\hline Unknown & $2(1.4)$ & $17(12.1)$ & $2(1.4)$ & $2(1.4)$ \\
\hline \multicolumn{5}{|l|}{$\begin{array}{l}\text { Type of anti-cancer } \\
\text { treatment }^{5}\end{array}$} \\
\hline Targeted therapy $^{6}$ & $63(44.1)$ & $316(38.4)$ & $63(44.1)$ & $63(44.1)$ \\
\hline $\begin{array}{l}\text { Targeted therapy - } \\
\text { Anti-CD20 antibodies }{ }^{7}\end{array}$ & $23(36.5)$ & $92(29.1)$ & $23(36.5)$ & $17(27.0)$ \\
\hline $\begin{array}{l}\text { Targeted therapy - } \\
\text { BTK inhibitors }^{7}\end{array}$ & $10(15.9)$ & $30(9.5)$ & $10(15.9)$ & $6(9.5)$ \\
\hline Cytotoxic chemotherapy & $25(17.5)$ & $213(25.9)$ & $25(17.5)$ & $29(20.3)$ \\
\hline Immunotherapy & $14(9.8)$ & $18(2.2)$ & $14(9.8)$ & $<5(3.5)^{8}$ \\
\hline \multicolumn{5}{|l|}{$\begin{array}{l}\text { U.S. census region of } \\
\text { patient residence }\end{array}$} \\
\hline Northeast & $68(47.6)$ & $400(48.6)$ & $68(47.6)$ & $71(49.7)$ \\
\hline Midwest & $35(24.5)$ & $183(22.2)$ & $35(24.5)$ & $26(18.2)$ \\
\hline West & $22(15.4)$ & $88(10.7)$ & $22(15.4)$ & $11(7.7)$ \\
\hline South & $18(12.6)$ & $152(18.5)$ & $18(12.6)$ & 35 (24.5) \\
\hline
\end{tabular}

${ }^{1}$ Percentages do not add to $100 \%$ because 2 patients had unknown method of diagnosis 
medRxiv preprint doi: https://doi.org/10.1101/2021.02.05.21250953; this version posted February 5, 2021. The copyright holder for this preprint (which was not certified by peer review) is the author/funder, who has granted medRxiv a license to display the preprint in perpetuity. All rights reserved. No reuse allowed without permission.

${ }^{2}$ Hospitalization status could not be verified for one patient receiving convalescent plasma; given that this treatment is given nearly universally in the hospital setting, the patient was retained for analysis

${ }^{3}$ Defined as absolute lymphocyte count less than $1.5 \times 10^{9}$ cells/liter

${ }^{4}$ Percentages add to more than $100 \%$ because some patients had multiple hematologic malignancies (synchronous or metachronous)

${ }^{5}$ Most recent treatment that was given within 3 months of COVID-19 diagnosis; patients may have received more than one modality

${ }^{6}$ Includes monoclonal antibodies, small molecule inhibitors, and immunomodulators

${ }^{7}$ These numbers may be underestimated; 70 of $512(13.7 \%)$ patients on active treatment did not have any individual drug information provided to the registry

${ }^{8}$ Cells other than missing/unknown with fewer than 5 patients are masked per CCC19 policy 
Table 2: Association between Convalescent Plasma use and Death in the Crude Analysis, Multivariable Analysis, and Propensity-Score Analyses.

\begin{tabular}{|c|c|}
\hline Analysis & Death in 30 days \\
\hline \multicolumn{2}{|l|}{ Overall Population } \\
\hline No. of events/no. of patients at risk (\%) & $223 / 966(23.1 \%)$ \\
\hline Convalescent plasma & $19 / 143(13.3 \%)$ \\
\hline No convalescent plasma & $204 / 823(24.8 \%)$ \\
\hline Crude analysis - hazard ratio $(95 \% \mathrm{Cl})^{\star}$ & $0.47(0.30-0.76)$ \\
\hline Multivariable analysis — hazard ratio $(95 \% \mathrm{Cl})^{\wedge}$ & $0.60(0.37-0.97)$ \\
\hline Propensity-score matching - hazard ratio $(95 \% \mathrm{Cl}) \#$ & $0.52(0.29-0.92)$ \\
\hline \multicolumn{2}{|l|}{ Subgroup requiring intensive care unit admission } \\
\hline No. of events/no. of patients at risk (\%) & $135 / 338(39.9 \%)$ \\
\hline Convalescent Plasma & $12 / 76(15.8 \%)$ \\
\hline No Convalescent Plasma & $123 / 262(46.9 \%)$ \\
\hline Crude analysis - hazard ratio $(95 \% \mathrm{Cl})^{*}$ & $0.26(0.14-0.47)$ \\
\hline Multivariable analysis — hazard ratio $(95 \% \mathrm{Cl})^{\wedge}$ & $0.30(0.16-0.56)$ \\
\hline Propensity-score matching - hazard ratio $(95 \% \mathrm{Cl}) \#$ & $0.40(0.20-0.80)$ \\
\hline \multicolumn{2}{|l|}{ Subgroup requiring mechanical ventilation } \\
\hline No. of events/no. of patients at risk (\%) & $105 / 227(46.3 \%)$ \\
\hline Convalescent Plasma & $8 / 45(17.8 \%)$ \\
\hline No Convalescent Plasma & $97 / 182(53.3 \%)$ \\
\hline Crude analysis - hazard ratio $(95 \% \mathrm{Cl})^{*}$ & $0.24(0.16-0.49)$ \\
\hline Multivariable analysis — hazard ratio $(95 \% \mathrm{Cl})^{\wedge}$ & $0.23(0.10-0.50)$ \\
\hline Propensity-score matching - hazard ratio $(95 \% \mathrm{Cl}) \#$ & $0.32(0.14-0.72)$ \\
\hline
\end{tabular}


medRxiv preprint doi: https://doi.org/10.1101/2021.02.05.21250953; this version posted February 5, 2021. The copyright holder for this preprint (which was not certified by peer review) is the author/funder, who has granted medRxiv a license to display the preprint in perpetuity.

All rights reserved. No reuse allowed without permission.

\begin{abstract}
${ }^{\wedge}$ Hazard ratio form multivariable stratified Cox proportional-hazard model, with stratification by trimester of diagnosis with additional covariate adjustment \# Marginal hazard ratio from propensity-score matched sample, constructed using 1:1 nearest neighbor matching with calipers of width equal to 0.2 of the standard deviation of the distance measure.
\end{abstract}


medRxiv preprint doi: https://doi.org/10.1101/2021.02.05.21250953; this version posted February 5, 2021. The copyright holder for this preprint (which was not certified by peer review) is the author/funder, who has granted medRxiv a license to display the preprint in perpetuity.

All rights reserved. No reuse allowed without permission.

\section{FIGURES}

A)

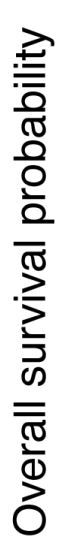

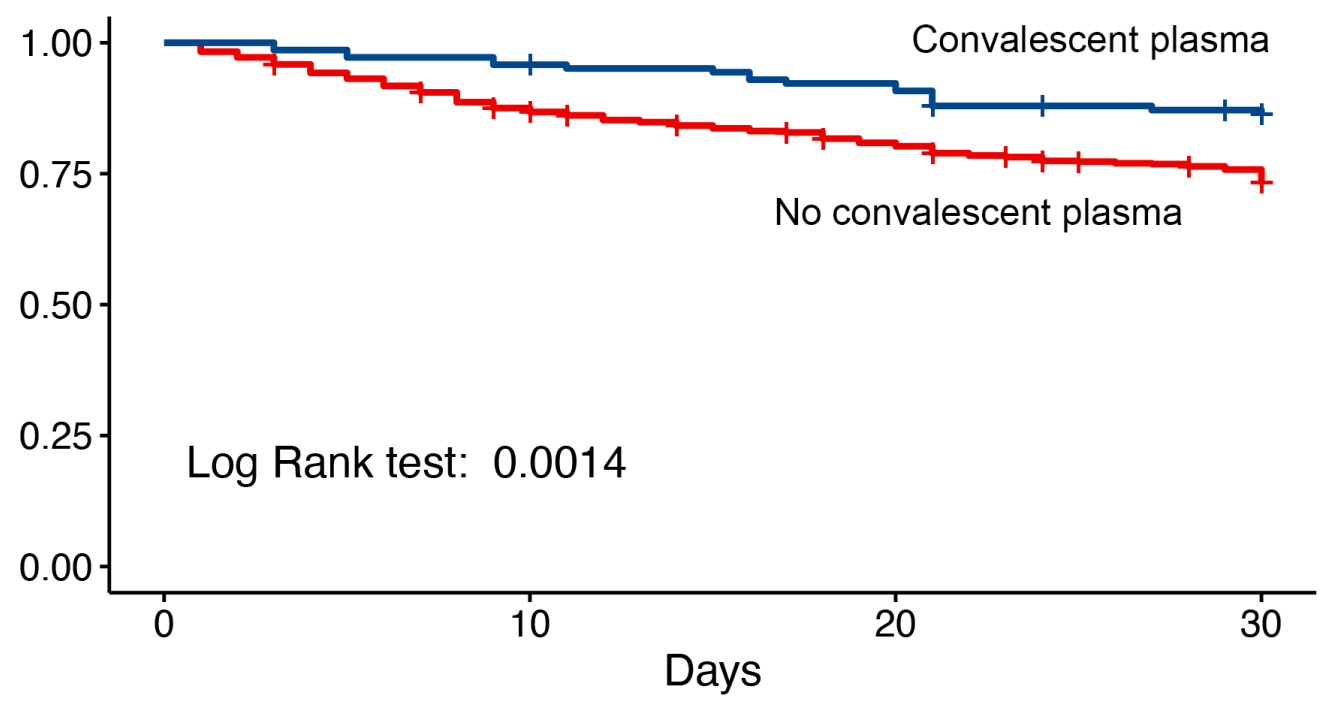

Number at risk

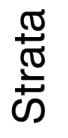

\begin{tabular}{cccc} 
Number at risk & & & \\
No CP $-\begin{array}{l}823 \\
\text { CP } 143\end{array}$ & 702 & 613 & 507 \\
143 & 137 & 129 & 108 \\
\hline 0 & 10 & 20 & 30
\end{tabular}

B)

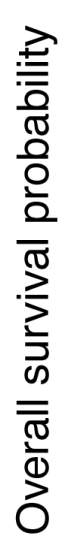

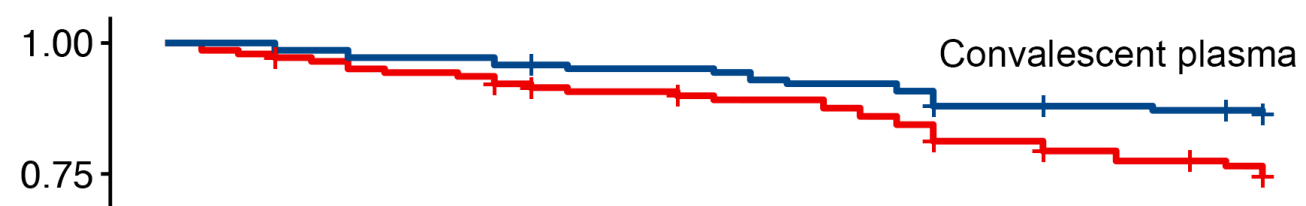

No convalescent plasma

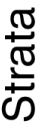

\begin{tabular}{cccc} 
Number at risk & & & \\
No CP- 143 & 128 & 109 & 79 \\
CP. 143 & 137 & 129 & 108 \\
\hline 0 & 10 & 20 & 30
\end{tabular}

Figure 1: Primary Outcome in the A) Overall Population and B) Propensity-Score 